\title{
Model Design of Adaptive Learning Analytics Management System (ALAMS) Using AID Model
}

\author{
Ence Surahman \\ Department of Educational Technology \\ Universitas Negeri Malang, Indonesia \\ ence.surahman.fip@um.ac.id \\ Dedi Kuswandi \\ Department of Educational Technology \\ Universitas Negeri Malang, Indonesia \\ dedi.kuswandi.fip@um.ac.id
}

\author{
Agus Wedi \\ Department of Educational Technology \\ Universitas Negeri Malang, Indonesia \\ agus.wedi.fip@um.ac.id \\ Zahid Zufar At Thaariq \\ Department of Educational Technology \\ Universitas Negeri Malang, Indonesia \\ zahidthoriq123@gmail.com
}

\author{
Risma Chulashotud Diana \\ Department of Educational Technology \\ Universitas Negeri Malang, Indonesia \\ risma.reynaldo@gmail.com
}

\begin{abstract}
The development of online learning in Indonesian tertiary institutions has made significant progress in the past decade. All colleges are competing to develop online learning services. However, most learning services are presented with the same model, which is to uniform all students. The developer views that all students can be served with the same service package. In fact, each student experiences a variety of learning styles. This study aims to design an online learning system that is adaptive to differences in the characteristics of students. The research method used is the AID development model (analysis, identification and design). At the analysis stage, researcher analyzing the weaknesses, and limitations of the existing LMS. While at the identification stage researchers identified new innovations from LMS that could be developed. While at the design stage, researchers conducted an adaptive online learning system design model design. After the model is designed, it is then validated by the model expert and online learning expert. Based on the design results obtained an adaptive learning analytic management system model that is feasible and can be developed in practice implementation.
\end{abstract}

Keywords: alams, adaptive learning, learning analitic, aid model, online learning

\section{INTRODUCTION}

The development of electronic learning systems that are blended (mixed) using the Learning Management System (LMS) platform has developed since the advent of the internet and its adoption in the world of learning. Learning using the Learning Management System (LMS) can be done blended (mixed) with face-to-face learning or full online. Both have advantages and limitations. Blended learning has a positive impact on the learning process and learning (Garrison \& Kanuka, 2004; Gilbert \& Flores-Zambada, 2011; Morris, 2014; Sharpe, Benfield, Roberts, \& Francis, 2006 in (Bralić, 2018).

There are many studies that examine online learning using LMS. However, most of these researchers develop general LMS regardless of differences in learning preferences. In fact, each student's learning preferences differ. For example, learning preferences based on sensory learners are divided into visual, auditory, and kinesthetic learning style preferences (Surahman E. S., 2017).

Students who are predominantly visual learning styles are characterized by feeling happy to see educators demonstrate material in front of the class, or reading textbooks, viewing videos and pictures in textbooks. As for students who have a predominantly auditory learning style tend to prefer teachers who present material orally, listen to material from audio recordings. While students who have a kinesthetic learning style preference are more likely to enjoy learning when they can do it, and their motor nerves are more fully activated.
(Prastiti, 2009) mention there are several theories and models about learning preferences and the factors that influence one's learning preferences. In general, learning preference models can be classified into three scopes, namely inssssformation processing, environment, and personality. Some instruments to assess a person's learning style have been developed by several experts, among others, developed by (Kolb, 1985) known as the Learning Style Inventory (LSI) or Kolb'LSI. Another model developed by Canfield is called the Learning Style Inventory (Canfield 'LSI) (Canfield, 1983).

The process of analyzing the needs and characteristics of students and the activities of students in learning is called analytical learning. Long dan Siemens (Dietz-Uhler, 2013) mention learning analytics as measuring, collecting, analyzing and reporting data about students and their contexts for the purpose of understanding and optimizing learning and the learning environment. Learning analytics are able to predict and increase the success of student retention because the decision making process in the learning process is based on data available in the learning management system (LMS) (Olmos \& Corrin, 2012, Jones, 2012; Long \& Siemens, 2011; Picciano, 2012 in (Dietz-Uhler, 2013). Learning analytics need to be adopted in learning management systems for the purpose of learning process data analysis.

The application of learning analytics also needs to be applied in the packaging of learning media presentations, given that media has an important role in 
learning. Kemp \& Dayton (Daryanto, 2010) explained that learning media has a contribution including: delivery of learning messages can be more standardized, learning can be more interesting, learning becomes more interactive by applying learning theory, learning implementation time can be shortened, the quality of learning can be improved, the learning process can be take place whenever and wherever needed, the positive attitude of students towards learning materials and the learning process can be improved, the role of the teacher experiences positive changes. Good multimedia development can meet the principles of personalized learning that is able to adjust to the characteristics of students (Maseleno, 2018).

Surjono (Surahman E. S., 2017) mentions the difference in learning preferences shows the fastest and best way for an individual to absorb information outside himself. In the context of learning, lecturers' efforts in packaging learning strategies and learning media are important to pay attention to the dominant learning styles of students, it aims to help students master the information and learning material quickly and accurately.

The diversity of learning preferences inspires individual learning approaches, namely learning approaches that seek to help students solve their problems personally. Since the problems of each student in learning are varied, efforts to help students solve the problems they face must also be done with an individual approach. Various efforts to help solving individual learning problems. One effort that can be taken is with adaptive learning, namely learning that is appropriate and appropriate to the needs and characteristics of students. In addition, adaptive with the level of intelligence of students to encourage themselves to master learning goals and adaptive to differences in learning styles that are dominant in him. The concept of adaptive learning avoids the element of coercion of services that are not in accordance with the user's learning preferences, it is in line with the concept of Ki Hadjar Dewantara's thought which carries the concept of education as an effort to free students (Hendratmoko, 2018).

The implementation of adaptive learning can also be realized in the selection of methods, strategies, materials, resources, assignments or evaluations as well as the development of learning media used in the learning process (Surjono, 2011). In the development of adaptive learning media including the birth of the concept of adaptive e-learning that has been proven effective in the process of achieving learning goals compared to nonadaptive e-learning (Surjono, 2011).

The design of an adaptive learning management system can be developed and studied more deeply, especially in the differences in learning strategies carried out in the LMS. Two learning strategies in LMS are synchronous and asynchronous. The synchronous strategy is carried out simultaneously between the facilitator and the learner. While the asynchronous strategy can be done without having to be online simultaneously. In this study, students as students are given the opportunity to express themselves in the form of learning outcomes documents. Learning management through individual, independent, group, and classical activities is expected to be able to increase student activity and creativity.
This study aims to develop a design model for adaptive learning management systems through learning analysis techniques that are carried out throughout the learning process. The results of this research are expected to be realized in the form of a model of Adaptive Learning Analitics Management System (ALAMS) that is feasible and can be used as a basis for developing practice.

\section{METHOD}

This study uses the AID development model. The AID development model is one of the development models suitable for product development to the design or prototype stages. AID consists of three steps namely analysis, identification and design. In general, the description of the AID model can be seen in the following Figure 1.

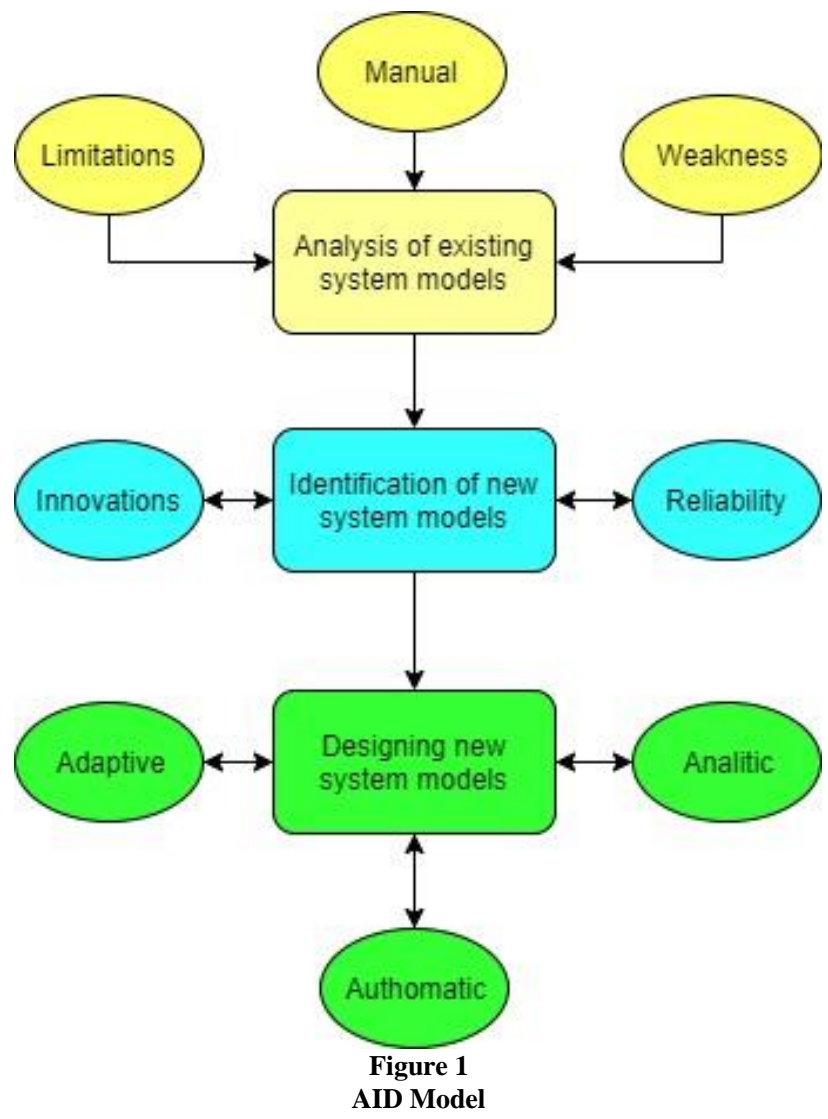

Based on Figure 1 above we can see the systematic process of developing ALAMS model design. The practical stages of the ALAMS model are illustrated as follows.

a. Analysis. This stage is the initial stage of the development process. The needs analysis aims to analyze the existence of the existing LMS model. Matters analyzed include weaknesses, limitations and manual systems that occur in the process. In addition, the analysis also aims to explore information about the diversity of students' learning styles in the Adaptive Learning Analytics Management System (ALAMS) program using learning style inventory. There are 25 questions that can identify learners' learning style preferences. Instruments to measure the diversity of learning styles are used to identify differences in 
learning styles of each student. In addition, the needs analysis process is carried out using an analytic approach (Schumacher, 2018). Some software needed for the LMS analysis process include Google analytics, Piwik analytics and Intelliboard.

b. Identification. This stage aims to identify possible new system models. At this stage the researcher is trying to find new features in the LMS that can be developed. This stage also aims to bring up the idea of innovation and measure the feasibility of the resulting innovation. If the innovation idea is possible to be developed, then the next step is to design the model.

c. Design. This stage aims to design an Adaptive Learning Analytics Management System (ALAMS) model. In addition, researchers included learning analytic features in the developed ALAMS model. The ALAMS model that has been designed is validated by colleagues to obtain input and improvement materials.

\section{RESULT}

The results of the analysis phase found some weaknesses of the existing LMS system including, LMS was designed with a general approach, meaning that LMS is presented by looking at all students having the same learning preferences. Another limitation found is the absence of analytical learning features that can be used as material by educators to make decisions at the stages of the learning process.

Furthermore, the results of the identification stage are in the form of findings of several innovative ideas that can be developed in the existing LMS system. There are at least two innovations that can be included namely the innovation of learning analysis features, the second innovation is learning style analysis features. Another innovation is the packaging of media and teaching materials that are able to facilitate the diversity of learning styles (Pardo, 2019).

At the design stage, the ALAMS model design is produced which illustrates an LMS model system that has additional features in the form of analytical learning features, learning style analysis features and packaging of materials that are compatible with diverse learning styles. In a simple ALAMS model produced can be seen in the following figure.

Based on Figure 2 above, you can explain some information as follows. L1, L2, L3 are visual information about students, each of whom has different learning characteristics. All students will enter the ALAMS system which is designed using the login menu which must first be registered. After students log in, before they access the material and services available, students must complete a learning style identification questionnaire.

There are 25 statements that must be chosen by students. In the process the students only choose statements that are in accordance with him. The results of each statement are then calculated to determine the most dominant learning style trends. The tendency of the learning style will be the basis for the development and presentation of the online teaching materials provided. In addition, learning outcomes are also used to determine the type of learning strategies, learning methods, learning media and learning evaluation used (Elias, 2011).

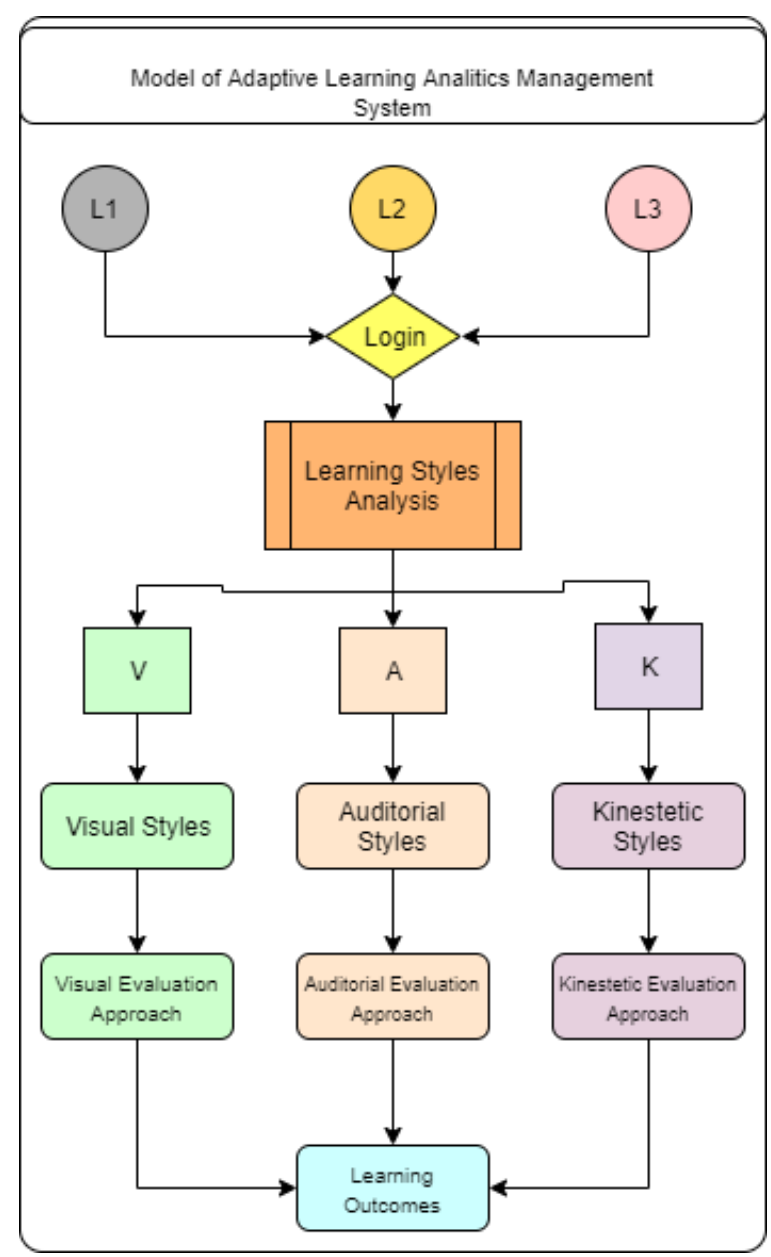

Figure 2

Adaptive Learning Analytics Management System Models

In the next stage it can be seen that students access material in accordance with their learning style tendencies. For students who have a visual learning style, the material is presented in the form of images, text, and video animation. As for students who have an inclination in auditory learning styles, teaching material is presented in the form of audio material that is packaged in an interesting and systematic way. The students who have kinesthetic learning styles are provided material in the form of games, work assignments, field activities and others.

Another adjusted pattern is a form of learning evaluation. Each student gets an evaluation service that is adjusted to their learning style trends. For students with visual learning styles, exam questions can be given in the form of written tests, or observations. Whereas for students with an auditory learning style evaluation of learning can be provided by audio presentation, both synchronous and asynchronous interviews. As for students who have a kinesthetic learning style evaluation can be presented in the form of performance tests that must be recorded in the form of video.

Performance tests can be adjusted according to the type of material being tested. However, the approach of the students is facilitated to practice directly what needs to be done, then send the results of the recording to the facilitator for assessment. In addition students with 
kinesthetic characteristics are suitable given assignments in the form of making projects. Project based learning can be done in blended learning mode (Kuswandi, 2018).

After a whole series of learning processes is carried out, each of them gets feedback on the results of the learning from the facilitator. Feedback aims to inform the performance of students. As well as reflection material for improvement in subsequent learning activities.

The design model that has been developed is then validated by the model expert and the learning expert. Obtained the following information.

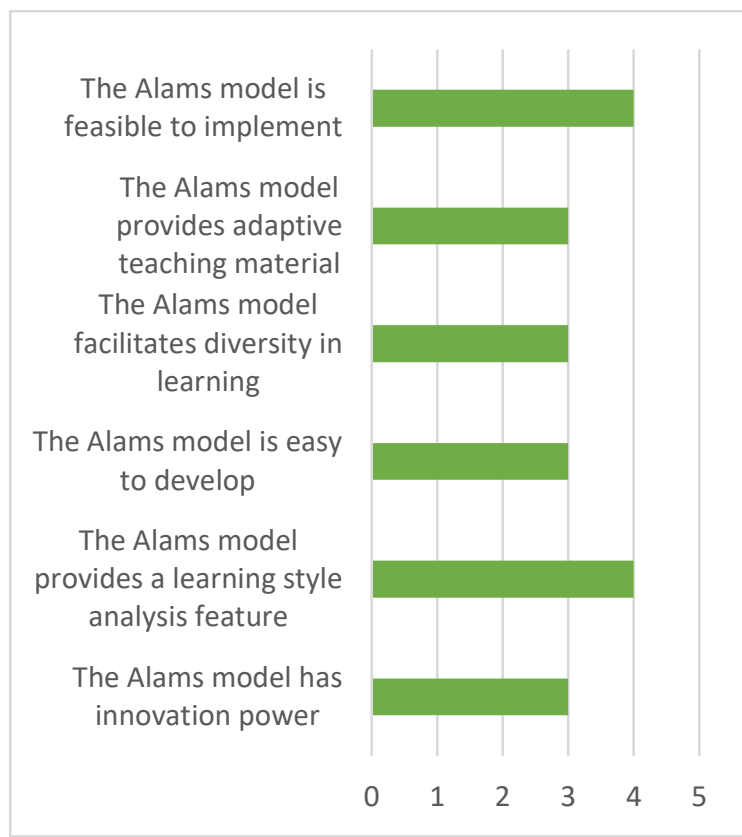

Figure 3
Expert judgment on the ALAMS model

Based on Figure 3 it can be explained that the expert model validator gave a positive assessment of the design of the Alams model that was developed. By using a 4 rating scale, a reasonable average is obtained. The first indicators of the natural model have a high degree of innovation, the validator answered in agreement. Then in the second indicator the model alams prepares the learning style analysis feature, the validator gives a value of 4 which means very much agree. Furthermore, the alams model indicator is easy to develop, the validator gives a value of 3 , which means agree. Furthermore, on the fourth indicator in the model statement, it facilitates learning diversity, the validator gives a score of 3 , which means agree. In the fifth statement on the statement of the natural model providing adaptive teaching material, the validator gives a score of 3 meaning agree. And in the fifth statement, the natural model deserves to be implemented, the validator gives a score of 4 meaning it is very agree.

\section{DISCUSSION}

Learning technology provides various facilities in designing, developing, implementing and assessing the learning process itself (Alfindasari, 2014). Learning management systems make it easy for educators to design blended learning, namely learning that is designed to be a mix of face-to-face and online (Bralić, 2018). Educators can also develop folded learning that is presenting material online and giving assignments in face-to-face meetings in class.

The use of learning managerment systems requires innovation to overcome the limitations of its weaknesses. Learning management systems that need to be given innovation in the form of adding features. Features that can be developed include the characteristics of student analysis characteristics. This feature can be developed using learning style identification instruments. The results of the learning style analysis are useful for packaging the presentation of learning material, the forms and learning strategies used, the methods and learning media presented (Dabbagh, 2005). Another thing is the form of learning evaluation that will be used.

Learning media presented in LMS must meet the principles of multimedia learning such as the principle of relevance, the principle of space closeness, the principle of coherence, and others (Surahman E. A., 2017). The development of learning media that meets the principles of good multimedia will make it easier for students to master the message contained therein.

In addition to learning style analysis features, other innovations in the form of learning analitics. Learning analitics is a new way that can be done to measure student performance in the developed LMS. Learning analitics can be done using data available on LMS (Maseleno, 2018). The data available can be about the amount of access to LMS, time to do assignments, time to access material, time to discuss, respond to questions and others (Schumacher, 2018).

Learning analysis data are also useful for decision making materials in learning design. The facilitator has accurate information when the right time is to present teaching materials online, the form of teaching material that students like. When is the most appropriate time to give assignments, how much time is needed to do a task (Berlanga, 2005). What type of assignments are liked by students and others.

The ALAMS model design has advantages in terms of the ability to analyze differences in students' learning styles. Then the ability to provide teaching materials in accordance with the tendency of learning styles. as well as the ability to provide approaches and evaluation forms of learning that are appropriate to students' learning styles. In addition, the learning analitics feature can provide good information for determining when to present material, when providing discussion forums, when giving assignments, when giving appropriate feedback to students. Feedback is a necessity in the era of digital learning (Mettler, 2011). It is able to provide authentic information to students about their shortcomings in learning. Research (Schumacher, 2018) shows that analytical learning can provide guidelines for students in planning and organizing learning experiences. These advantages can increase the variety of features and forms of learning services that can be presented in the developed LMS. The addition of these innovative features is expected to improve the quality and effectiveness of learning. The more effective the learning process is implemented, it will improve the quality of human 
resources (Surahman E. , 2019). Educational technology has a strategic role in efforts to improve the quality of Indonesian education human resources (Alfindasari, 2014).

\section{CONCLUSION}

Based on the data presentation in the results section and comparative analysis in the discussion section, it can be concluded that the design model of the adaptive learning analytical management system (ALAMS) developed using the AID model has been successfully realized. Based on expert assessment of learning models it can be concluded that the ALAMS model is feasible to be developed and implemented. Online learning management systems that are adaptive to the diversity of characteristics of students need to be designed to find a new innovation in the development of online learning services. The ALAMS system design that is produced is in the form of an online learning system model consisting of the stages of analyzing the needs of a learning management system, analyzing students' learning styles, identifying weaknesses and limitations, and identifying new features that can be developed, then designing an online learning platform. To find out more about the usefulness of the ALAMS model, it is necessary to develop practice and test the results of its development. So we can find out its reliability, effectiveness, including ease of use from the perspective of the instructor and students.

\section{ACKNOWLEDGEMENT}

The author would like to thank LP3 UM and ISDB who have funded research into the development of the ALAMS model on the 2018 Inobel grant.

\section{REFERENCES}

[1] Alfindasari, D. S. (2014). Sumber Daya Manusia dan Pendidikan di Era Global: Sebuah Tinjauan Terhadap Penelitian Teknologi Pendidikan di LPTK. In Proceeding Seminar Nasional Teknologi Pembelajaran. Yogyakarta: UNY.

[2] Berlanga, A. \&. ( 2005). Learning technology specifications: semantic objects for adaptive learning environments. International Journal of Learning Technology, 1(4), 458-472.

[3] Bralić, A. \&. (2018). Integrating MOOCs in traditionally taught courses: achieving learning outcomes with blended learning. International Journal of Educational Technology in Higher Education, 15(1), 2.

[4] Canfield, A. a. (1983). Learning Style Inventory. Los Angeles: Western Psycological Services.

[5] Dabbagh, N. \&.-R. (2005). Online learning: Concepts, strategies, and application (pp. 68-107). Upper Saddle River: Pearson/Merrill/Prentice Hall.
[6] Daryanto. (2010). Media pembelajaran peranannya sangat penting dalam mencapai tujuan pembelajaran. Yogyakarta: Gava Media.

[7] Dietz-Uhler, B. \&. (2013). Using learning analytics to predict (and improve) student success: A faculty perspective. Journal of interactive online learning, 12(1), $17-26$.

[8] Elias, T. (2011). Universal instructional design principles for mobile learning. The International Review of Research in Open and Distributed Learning,, 12(2), 143-156.

[9] Hendratmoko, T. K. (2018). Tujuan Pembelajaran Berlandaskan Konsep Pendidikan Jiwa Merdeka Ki Hajar Dewantara. . JINOTEP (Jurnal Inovasi dan Teknologi Pembelajaran) Kajian dan Riset dalam Teknologi Pembelajaran, 3(2), 152-157.

[10] Kolb, D. A. (1985). Learning-style inventory: Self-scoring inventory and interpretation booklet. Boston: MCBER and Company.

[11] Kuswandi, D. S. (2018). K-Means Clustering of Student Perceptions on Project-Based Learning Model Application. In 2018 4th International Conference on Education and Technology (ICET) (hal. (pp. 9-12)). Malang: IEEE.

[12] Maseleno, A. S. (2018). Demystifying learning analytics in personalised learning. International Journal of Engineering \& Technology, 7(3), 1124-1129.

[13] Mettler, E. M. (2011). Improving Adaptive Learning Technology through the Use of Response Times. Grantee Submission.

[14] Pardo, A. J. (2019). Using learning analytics to scale the provision of personalised feedback. British Journal of Educational Technology, 50(1), 128-138.

[15] Prastiti, S. D. (2009). Pengaruh faktor preferensi gaya belajar terhadap prestasi belajar mahasiswa akuntansi. Jurnal ekonomi bisnis, 14(3), 20-35.

[16] Schumacher, C. \&. (2018). Features students really expect from learning analytics. Computers in Human Behavior, 78, 397-407.

[17] Surahman, E. (2019). Integrated Mobile Learning System (Imoles) Sebagai Upaya Mewujudkan Masyarakat Pebelajar Unggul Era Digital. JINOTEP (Jurnal Inovasi dan Teknologi Pembelajaran) Kajian dan Riset dalam Teknologi Pembelajaran, 5(2), 50-56.

[18] Surahman, E. A. (2017). Developing Adaptive Mobile Learning with the Principle of Coherence Mayer on Biology Subjects of High School to Support the Open and Distance Education. 3rd International Conference on Education and Training (ICET 2017). 128, hal. 184-190. Malang: Atlantis Press. doi:https://doi.org/10.2991/icet17.2017.31

[19] Surahman, E. S. (2017). Pengembangan adaptive mobile learning pada mata pelajaran biologi SMA sebagai upaya mendukung proses blended learning. Jurnal Inovasi Teknologi Pendidikan, 4(1), 26-37.

[20] Surjono, H. D. (2011). The Design of Adaptive ELearning System Based on Student's Learning Styles. International Journal of Computer Science Information and Education Technologies (IJCSIT), 2(5), 2350-2353. 